\title{
Recuperación y resignificación del Barroco histórico en exposiciones de arte contemporáneo
}

\section{Recovery and resignification of the historical Baroque in contemporary art exhibitions}

\author{
(D) PATRICIA MANZANO RODRÍGUEZ \\ Universidad de Durham \\ patricia.manzano-rodiguez@durham.ac.uk
}

\begin{abstract}
Resumen: Con el fin de entender cómo se manifiesta el interés por el Barroco en los discursos curatoriales dentro de nuestro país, se han analizado tres exposiciones celebradas en la primera década del siglo XxI que evidencian la relación entre el arte contemporáneo y el Barroco histórico. Los casos de estudio elegidos son: Barrocos y Neobarrocos, Principio Potosí y El d_efecto barroco. A partir de estas exposiciones, se estudian las estrategias discursivas seguidas por dichos proyectos curatoriales en su intento de resignificación y recuperación del Barroco histórico desde la modernidad. Por un lado, en ellos se aprecia cómo el Barroco se ha convertido en un medio para la construcción de identidades, a través de temáticas como la relación entre España y América Latina o el uso de la imagen al servicio del poder como instrumento de propaganda. Por otro, las muestras han introducido el Neobarroco como una respuesta al posmodernismo en los discursos expositivos de nuestro país.
\end{abstract}

Palabras clave: Barroco, Neobarroco, identidad nacional, comisariado, poscolonialismo.

Abstract: In order to understand how the interest in Baroque art is manifested in the Spanish curatorial discourses, this article analyses three exhibitions held within the first decade of the twenty-first century for the purpose of demonstrating the relationship between contemporary art and the historical Baroque. The chosen case studies are Barrocos y Neobarrocos, The Potosi Principle and El d_efecto barroco. This article covers the discursive strategies followed by these curatorial projects in their attempt to re-signify and recover Baroque art from a modern point of view. On the one hand, they show how the Baroque has become a means for the construction of identities, through themes such as the relationship between Spain and Latin America or the use of images as an instrument of propaganda. On the other hand, the exhibitions have introduced the NeoBaroque as a response to postmodernism in the Spanish exhibition context.

Keywords: Baroque, Neo-Baroque, national identity, curated, postcolonialism.

Recibido: 27 de enero de 2020; aceptado: 25 de mayo de 2020; publicado: 30 de septiembre de 2020.

Revista Historia Autónoma, 17 (2020), pp. 111-131

e-ISSN: 2254-8726; https://doi.org/10.15366/rha2020.17.006 
El escritor cubano Severo Sarduy escribió en sus ensayos sobre el Barroco que "no es posible pensar en la modernidad, aunque sea de un modo crítico, sin dejar de lado su momento barroco"1. Desde entonces, el interés por relacionar el Barroco y el arte contemporáneo ha ido en aumento y recientemente se ha trasladado a museos y galerías.

Con el fin de entender cómo se manifiesta el interés por el Barroco en los discursos expositivos dentro de nuestro país, se han elegido tres exposiciones celebradas en la primera década del siglo XXI que evidencian la relación entre el arte contemporáneo y el Barroco histórico. Los casos de estudio escogidos son: Barrocos y Neobarrocos. El infierno de lo bello, Principio Potosí: ¿cómo podemos cantar el canto del Señor en tierra ajena? y El d_efecto barroco. Políticas de la imagen hispana. En estas exposiciones el arte del siglo XVII conversa con propuestas artísticas actuales. Las muestras se han seleccionado en base a criterios geográficos y temporales: todas fueron celebradas en instituciones públicas de diferentes ciudades españolas en un periodo de cinco años. Además, cada uno de los ejemplos elegidos muestra aspectos originales sobre nuestra forma de repensar el pasado.

Barrocos y Neobarrocos, visible del 3 de octubre de 2005 al 8 de enero de 2006, fue comisariada por Francisco Javier Panera Cuevas, el entonces director del Domus Artium 2002, y se centró en el aspecto transgresor del Barroco. La exposición contaba con la colaboración de más de setenta artistas nacionales e internacionales que produjeron obras que citan literalmente el Barroco histórico y lo reinterpretaban desde el presente, obras que desde un punto de vista formalista podrían ser consideradas barrocas por elementos como la ornamentación o la tendencia al exceso, y obras "conceptualmente barrocas" que promovían el tipo de juegos laberínticos que Deleuze y Calabrese identifican con el Neobarroco². Así, se establecía el Barroco como un arte de periodos de transición a través de conceptos clave como el Neobarroco, el mestizaje, la metáfora y la alegoría.

Principio Potosí y El d_efecto Barroco se llevaron a cabo en un ambiente distinto, pero también cargado de connotaciones políticas. En 2010 se celebró el bicentenario de la independencia de algunas colonias latinoamericanas: México, Venezuela, Argentina, Ecuador, Colombia, Chile y Bolivia. Principio Potosí fue una exposición comisariada por un grupo de teóricos internacionales de perfiles variados: la artista y teórica alemana Alice Creischer, el filósofo y escritor brasileño Max Jorge Hinderer y el historiador del arte alemán Andreas Siekmann. La muestra se pudo visitar en el Museo Reina Sofía del 12 de mayo al 6 de octubre de 2010 y después itineró por la Casa de las Culturas del Mundo (Haus der Kulturen der Welt) de Berlín y por el Museo de Etnografía y Folklore de La Paz. Principio Potosí buscaba repensar la modernidad a partir de la pintura colonial barroca, producida en parte gracias a la plata que se

\footnotetext{
${ }^{1}$ Panera Cuevas, Francisco (ed.), Barrocos y Neobarrocos: el infierno de lo bello, catálogo de la exposición (Salamanca, Domus Artium 2002, del 3 de octubre de 2005 al 8 de enero de 2006), Salamanca, Fundación Salamanca Ciudad de Cultura, 2005, p. 5.

${ }^{2}$ Ibídem, pp. 29-31.
} 
extraía del Cerro Rico de Potosí, que llegó a ser una de las ciudades más importantes del mundo durante la Edad Moderna.

La relación entre arte contemporáneo, Barroco y colonialismo también está presente en El d_efecto barroco, muestra comisariada por los historiadores del arte Jorge Luis Marzo y Tere Badia. El tema principal de la exposición, que ocupó el Centro de Cultura Contemporània de Barcelona (en adelante CCCB) del 9 de noviembre de 2010 al 27 de febrero de 2011, fue la gestión de las políticas culturales de nuestro país y la imagen que proyectamos en el extranjero. El Barroco aquí se entendía no como un movimiento artístico sino como una herramienta de propaganda, identificando lo hispano como una cualidad intrínsecamente barroca que conecta España con Latinoamérica ${ }^{3}$.

El objetivo del presente trabajo es estudiar cómo y por qué se le ha concedido tanto protagonismo al Barroco en exposiciones de arte contemporáneo en la primera década del siglo XXI. Para ello, estas exposiciones permitirán reflexionar sobre dos cuestiones principales que, como vemos, se repiten en cada una de ellas. En primer lugar, la articulación del discurso barroco como medio para la construcción de identidades, estudiando la relación entre el Barroco y la hispanidad. Para esto, es imprescindible entender la conexión entre España y América Latina —durante la Edad Moderna y actualmente - y las consecuencias del colonialismo. El "relato barroco", por tanto, se aleja de lo meramente artístico para convertirse en una nueva política cultural. En las tres exposiciones, con matices, el Barroco se presenta como un sistema sociopolítico (más que cultural) en el que la imagen está al servicio del poder y sirve para proyectar el concepto de hispanidad fuera de España. La segunda cuestión será determinar si estas exposiciones pueden considerarse "neobarrocas", con todo lo que eso conlleva. Estas muestras surgen del deseo de revisar el Barroco desde la modernidad y pretenden legitimar el discurso neobarroco como una respuesta al posmodernismo mediante un lenguaje artístico que se ajusta de forma consciente al arte del siglo XVII.

Uno de los aspectos más arduos a la hora de abordar el tema que nos ocupa ha sido la definición de términos como "Neobarroco" o "hispanidad". Conscientes de que estos conceptos están abiertos a varias interpretaciones, las definiciones con las que hemos trabajado están sujetas a la visión de los comisarios de las exposiciones tratadas dentro de la presente investigación. Dicho esto, el término "Neobarroco" se consolidó durante los años ochenta dentro del campo de la semiótica para definir el gusto de nuestro tiempo. Calabrese en La era neobarroca buscaba encontrar cualidades que definieran nuestra época y ante el declive del posmodernismo propuso este nuevo concepto, entendiendo el Barroco no como un periodo histórico, sino como una actitud $^{4}$. Desde finales de los años ochenta, esta idea la han continuado autores como Severo

\footnotetext{
${ }^{3}$ Marzo, Jorge Luis, La memoria administrada. El Barroco y lo hispano, Madrid, Katz, 2010, p. 59. https://doi. org/10.2307/j.ctvm $7 \mathrm{bc} 7 \mathrm{j}$

${ }^{4}$ Calabrese, Omar, La era neobarroca, Madrid, Cátedra, 1999, p. 31.
} 
Sarduy, Peter Wollen o Gilles Deleuze, fundamentales para definir el Neobarroco no como un estilo artístico sino como un producto de la posmodernidad ${ }^{5}$.

La mayoría de los ensayos sobre Neobarroco parten de la Monadología del filósofo alemán Gottfried Leibniz, que establece que todo está relacionado para formar una unidad total $^{6}$. A partir de este texto, publicado por primera vez en 1720, Deleuze elaboró una teoría filosófica centrada en el pliegue barroco. Sin embargo, no se entiende el pliegue como el alarde de maestría a la hora de representar ropajes que hizo famosos a Bernini o Zurbarán. El pliegue deleuziano es una cualidad metafísica que trasciende las obras de arte y llega hasta el infinito.

En España, el Círculo de Bellas Artes celebró en 1990 un ciclo de conferencias bajo el título "El Barroco y su doble" Con excepción de este debate y de las publicaciones de José Luis Brea sobre el Barroco en la contemporaneidad ${ }^{8}$, el Neobarroco como corriente teórico-crítica ha tenido poco recorrido en nuestro país. Sin embargo, fuera de nuestras fronteras recientemente se ha definido una "segunda ola" neobarroca que surge a partir de finales del siglo xx y principios del siglo XXI". Este nuevo Neobarroco se presenta como el resultado de las transformaciones culturales en la era digital, en un proceso similar al del siglo XVII. Esta es también la concepción que tiene Panera Cuevas sobre el Neobarroco, que lo define como:

\begin{abstract}
Una categoría estética [...] con estrategias de representación propias. Una metáfora de nuestro tiempo que retoma y redefine - a veces de un modo contradictorio - comportamientos estéticos y socioculturales que se extienden desde la antigüedad clásica hasta hoy. ${ }^{10}$
\end{abstract}

En cuanto a la relación entre el Barroco, América Latina y el colonialismo, este proyecto ha seguido las premisas del programa de investigación de modernidad/colonialidad de la Universidad de Carolina del Norte ${ }^{11}$, ultimando: primero, que la colonialidad es un rasgo de la modernidad y por tanto no puede haber una sin la otra; que el mundo moderno/colonial se origina en el siglo XVI con el descubrimiento o invención de América y su vertiente visible es el Renacimiento europeo; $y$, por último, que el capitalismo es esencial para entender modernidad y colonialidad. A esto hay que sumarle los cambios geopolíticos que describe Mignolo en The idea of Latin America (2005), concluyendo que algunas de las consecuencias del proceso de

\footnotetext{
${ }^{5}$ Ver: Sarduy, Severo, Barroco, París, Editions du Seuil, 1975; Wollen, Peter, "Baroque and Neobaroque in the age of spectacle", en Point of Contact, 3 (1993), pp. 9-21; Deleuze, Gilles, El pliegue. Liebniz y el barroco, Barcelona, Paidós, 1989.

${ }^{6}$ Ver: Leibniz, Gottfried Wilhelm, Monadología: principios de filosofía, Madrid, Biblioteca Nueva, 2001.

${ }^{7}$ Buci-Glucksmann, Christine (ed.), Volumen 2 de cuadernos del Círculo: Barroco y Neobarroco, Madrid, Círculo de Bellas Artes, 1993

${ }^{8}$ Brea, José Luis, Nuevas estrategias alegóricas, Madrid, Tecnos, 1991.

${ }_{9}^{9}$ Ndalianis, Angela, Neo-baroque aesthetics in contemporary entertainment, Cambridge, MIT Press, 2004 , p. 17. https://doi.org/10.7551/mitpress/4912.001.0001

${ }^{10}$ Panera Cuevas, Francisco, Barrocos y Neobarrocos... op. cit., 2005, p. 10.

${ }^{11}$ Escobar, Arturo, "Mundos y conocimientos de otro modo", en Tabula Rasa, 1 (2003), pp. 51-86. https://doi. org/10.25058/20112742.188
} 
conquista y colonización fueron la expansión geográfica del mundo, el desarrollo de métodos de control de producción y trabajo y la creación de maquinarias de control del Estado ${ }^{12}$.

\section{Barrocos y Neobarrocos: qué significa ser barrocos en el siglo XXI}

¿Podemos encontrar características comunes que definan el arte de nuestro tiempo? Esta es la cuestión principal que intenta responder el semiólogo italiano Calabrese en La era Neobarroca. Esta, también, es la pregunta que se hizo Panera Cuevas a la hora de plantear una exposición como Barrocos y Neobarrocos. El infierno de lo bello de la mano de setenta artistas nacionales e internacionales en el Domus Artium 2002 de Salamanca. El objetivo era que Barrocos y Neobarrocos se convirtiese en "un dispositivo de reflexión sobre las contradicciones del presente y sus síntomas, pero al mismo tiempo que fuese una exposición para el disfrute"13.

Tal y como se concibe en Barrocos y Neobarrocos, el Neobarroco puede ser muchas cosas: desde internet hasta la cirugía plástica, pasando por el cine o los cómics de Batman. Es más, la reedición del catálogo de la muestra no duda en comparar la famosa escultura clásica del Laocoonte con una imagen del monstruo de la película Aliens: El regreso (James Cameron, 1986), o los famosos frescos de Pietro da Cortona en el Palazzo Barberini de Roma (1639) con la obra del artista alemán Franz Ackermann. Todo ello es arte (neo)barroco aunque se realizara mucho antes o de forma posterior a lo que identificamos como el Barroco histórico. Actualmente, la tendencia al exceso, la dramatización en nuestra vida diaria y los dispositivos de propaganda política a los que estamos expuestos simbolizan que vivimos, como explica Panera Cuevas, en un mundo Neobarroco.

La muestra, inaugurada en 2005, contaba con Paco Barragán y Omar-Pascual Castillo como comisarios invitados y se diseñó como una vanitas divida en tres espacios administrados por el ayuntamiento salmantino. La exposición se celebró coincidiendo con el 250 aniversario de la construcción de la Plaza Mayor de Salamanca, centro neurálgico de la ciudad e inspiración de este proyecto. Pero el Barroco salmantino es solo el punto de partida. Para entender el concepto de Neobarroco con el que se trabajó en el Domus Artium es imprescindible definir primero este fenómeno cultural.

El Neobarroco no pretende volver al arte que se hacía en la Edad Moderna. Si Calabrese usa el prefijo "neo-" para denominar a este movimiento - y quizás lo primero tendría que ser determinar si es un movimiento, un estilo o una corriente- es porque reconoce que ciertas

\footnotetext{
${ }^{12}$ Mignolo, Walter, The Idea of Latin America, Oxford, Blackwell, 2005, p. 46.

${ }^{13}$ Panera Cuevas, Francisco (ed.), Barrocos y Neobarrocos: el infierno de lo bello, reedición del catálogo de la exposición (Salamanca, Domus Artium 2002, del 3 de octubre de 2005 al 8 de enero de 2006), Salamanca, 2007, p. 64.
} 
formas de varios fenómenos culturales evocan el Barroco histórico ${ }^{14}$. Esta premisa se basa en las afirmaciones de Eugenio d'Ors, que en una conferencia en Pontigny en 1931 llegó a identificar veintidós variaciones del Barroco a lo largo de la historia basándose en el sistema de clasificación de seres vivos ideado por Linneo en el siglo XVIII ${ }^{15}$. En base a esto, d'Ors habla en clave formalista de, por ejemplo, un barroco macedonio en época de Alejandro Magno o un barroco basado en el gótico internacional. Lo que tienen en común estos periodos históricos tan dispares es que son momentos de apertura y globalización. En este sentido, tanto el Barroco como el Neobarroco se han definido como periodos que surgen en momentos de crisis o como estados de transición entre dos sistemas, ya sean sociales, políticos o culturales ${ }^{16}$.

Por ejemplo, a nivel global, la revolución tecnológica de finales del siglo xx y principios del XXI no es diferente a la que se vivió en el siglo XVII. La observación sistemática del satélite por Galileo, Thomas Harriot y sus contemporáneos desveló imperfecciones en los cuerpos supralunares que supusieron un profundo cambio epistemológico que desembocó, por un lado, en la primera Revolución Científica y, por otro, en una profunda crisis de fe. Esto, unido al conocimiento sobre un nuevo continente y el cisma religioso que provocó la Reforma en el siglo XVI, es precisamente la pérdida de "integridad, globalidad y sistemización ordenada"17 a la que se refiere Calabrese al definir el Neobarroco y produce la misma inestabilidad que encontramos hoy en día en la era post-internet. Al igual que en el siglo XVII, es el progreso lo que provoca la crisis del conocimiento. En este caso, el momento de transición que estamos viviendo desde finales del siglo xx es el paso de una sociedad analógica a una completamente digital. El avance tecnológico es imparable pero la sensación de crisis que vivimos en el cambio de siglo no se ha desvanecido, y es que el Barroco es un lenguaje de contradicciones.

Esta noción se remonta a la propia etimología del término, que viene de la palabra portuguesa berrueco, usada para denominar las perlas deformes e imperfectas ${ }^{18}$. De ahí también que lo barroco tradicionalmente se haya identificado con otros términos peyorativos como exceso, extravagancia, caos. La dicotomía es inevitable, especialmente cuando tenemos en cuenta que el Barroco, asociado desde el siglo XIX a la construcción de la identidad hispánica, constituye por un lado nuestro Siglo de Oro pero, por otro, estuvo marcado por una fuerte crisis política y económica que desembocó en la pérdida definitiva de la hegemonía española en Europa.

En muchos aspectos, Barrocos y Neobarrocos fue una exposición pionera en España. El Neobarroco no tuvo la misma repercusión aquí que en el resto de Europa y Latinoamérica y no es de extrañar, pues aún sin haber digerido la modernidad entramos directamente en el debate

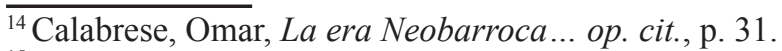

${ }^{15}$ D’Ors, Eugenio, Lo barroco, Madrid, Tecnos, 1993, pp. 59-100.

${ }^{16}$ Panera Cuevas, Francisco, Barrocos y Neobarrocos... op. cit., 2005, pp. 20-21.

${ }^{17}$ Calabrese, Omar, La era Neobarroca... op. cit., p. 10.

${ }_{18}$ Pérez Bazo, Javier, "El Barroco y la cuestión terminológica", en Panera Cuevas, Francisco, Barrocos y Neobarrocos... op . cit., 2005, pp. 92-123.
} 
posmoderno $^{19}$. Pese a todo, este fue el primer proyecto de nuestro país en introducir el concepto de Neobarroco como eje principal de un discurso expositivo. También cabe destacar que de las tres exposiciones analizadas en el presente trabajo, Barrocos y Neobarrocos fue la única que no incluyó obras producidas durante la Edad Moderna (o copias de las mismas). El discurso se elaboró exclusivamente a partir de obras contemporáneas. En la exposición se contaba con todo tipo de géneros y formatos, principalmente pintura, escultura, instalación y fotografía (fig. 1). Con el fin de ilustrar este arte de tiempos de transición y crisis, en Barrocos y Neobarrocos se presentaron obras que "traducían" el Barroco histórico o bien de forma literal, o bien a través de lo que el comisario denominó premisas "metabarrocas", para referirse a un arte barroco conceptual $^{20}$.

Figura 1: Sala de exposición de Barrocos y Neobarrocos. El Infierno de lo bello.

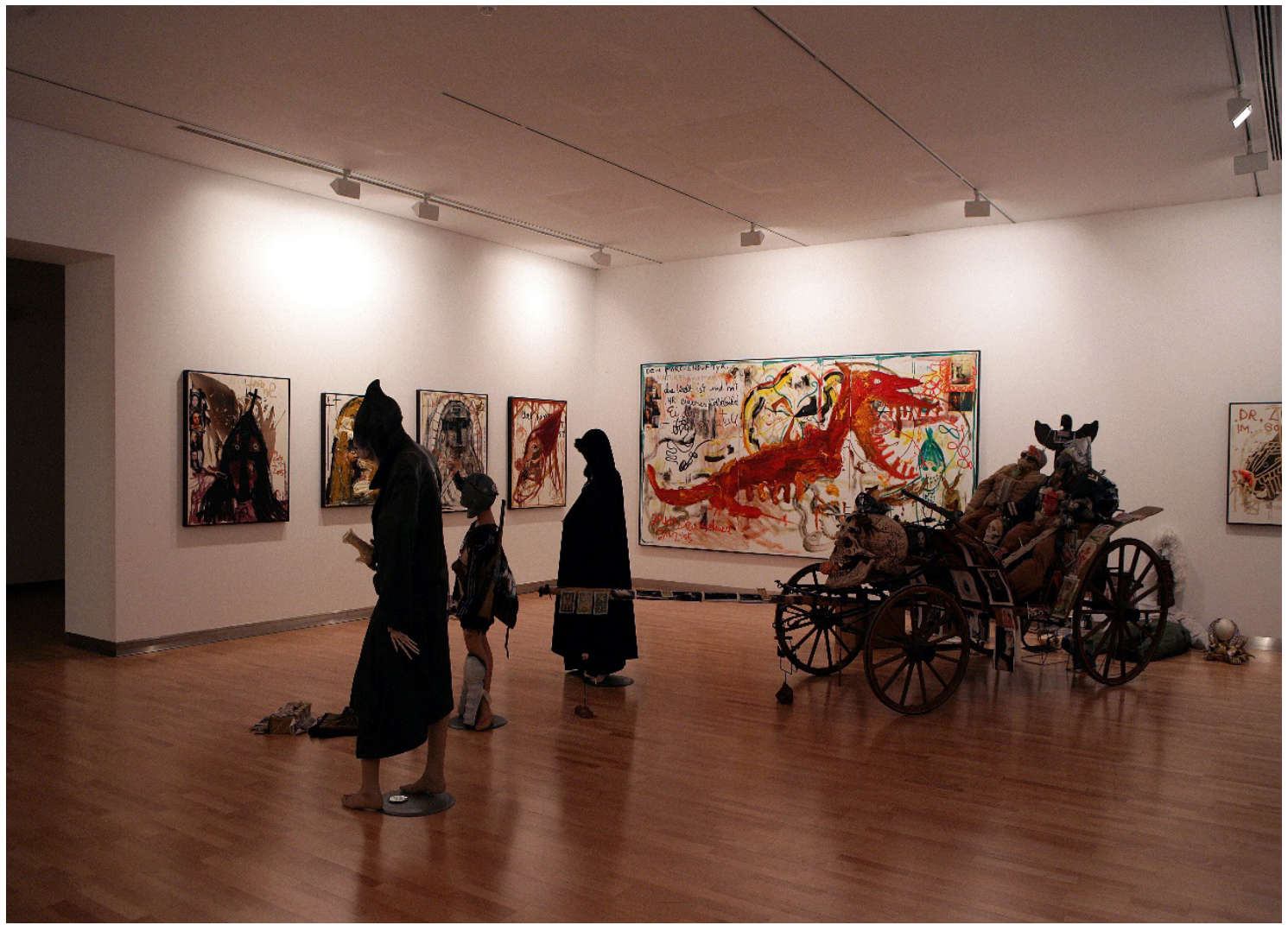

Fuente: Fotografía cedida por Francisco Javier Panera Cuevas, comisario de la muestra.

Conscientemente, algunos de los artistas se ajustaron a los géneros más practicados de la pintura barroca: el retrato, la pintura religiosa y el bodegón. En cambio, algunos de los aspectos formales que recuerdan de forma conceptual al estilo del Siglo de Oro son la tendencia al exceso, la alegoría, la ornamentación y los juegos de espejos. Esta interpretación del Neobarroco, la

\footnotetext{
${ }_{19}^{19}$ Marzo, Jorge Luis y Patricia Mayayo, Arte en España (1939-2015). Ideas, prácticas, políticas, Madrid, Cátedra, 2015, pp. 504-517.

${ }^{20}$ Panera Cuevas, Francisco, Barrocos y Neobarrocos... op. cit., 2005, pp. 30-31.
} 
menos literal, es la que interesaba a los comisarios. Así, además de los conceptos clave que usa Calabrese para definir el Neobarroco (límite, exceso, ritmo, repetición, metamorfosis, laberinto) a la exposición se le añaden algunas de las preocupaciones de los artistas barrocos que siguen vigentes hoy en día. Por ejemplo, la relación entre el Neobarroco y la posmodernidad o contramodernidad, la sensorialidad, la metáfora de la perla deformada.

Lo neobarroco va indudablemente unido a factores socioculturales que sobrepasan lo puramente estético. La importancia del factor social va a ser de vital importancia en la exposición y en todo el movimiento neobarroco. Unido a la noción de crisis y transición, una de las principales preocupaciones de Barrocos y Neobarrocos era la de reflejar una visión del Neobarroco más conforme al cambio de paradigma que se ha producido desde finales de los ochenta y sus consecuencias en las prácticas artísticas contemporáneas. El malestar y la turbación van a ser los detonantes de estos artistas.

En Barrocos y Neobarrocos quedó reflejada la lucha constante entre la teatralidad barroca y la crítica. La trampa, como nos explica el comisario, está en confiar en la belleza. El subtítulo de la exposición ("el infierno de lo bello") en una clara referencia a la Estética de lo feo de Rosenkranz (1853) ${ }^{21}$, nos advierte sobre la belleza culpable, aquella capaz de hacer que nos olvidemos del aparato crítico que rodea una obra o una exposición. Esto es algo que los comisarios querían evitar, pues Barrocos y Neobarrocos es, ante todo, una exposición crítica con las corrientes teóricas de finales del siglo xx y su repercusión en el arte. Por esta razón, aunque el Neobarroco no es una recuperación de un estilo del pasado, sí que supone la reactivación del imaginario barroco en todo su esplendor.

La vertiente del Barroco que se recupera en Barrocos y Neobarrocos es la del estilo artístico que nace en Europa tras la Contrarreforma. La transformación y la transición de un sistema a otro es, como hemos visto, una de las características principales de todos los momentos barrocos a lo largo de la historia, pero es que además algunos artistas contemporáneos van a ver en el ritual católico barroco una fuente de inspiración para sus obras ${ }^{22}$.

Algunas de estas referencias eran bastante claras, ya que muchas de las piezas que se expusieron en el Domus Artium introdujeron motivos religiosos, ya fuera como elementos simbólicos o en forma de vanitas. Otras, en cambio, pretendían recrear el rito barroco desde la contemporaneidad. Esto se hizo posible gracias a la vertiente más teatral del Barroco histórico, que en el lenguaje neobarroco se traduce en elaboradas puestas en escena. Barrocos y Neobarrocos apostó por obras que convierten el arte en una experiencia sensorial. Tal y como se explicita en el catálogo, lo más parecido hoy en día a una misa católica sería "la celebración una fiesta tecno aderezada con sustancias psicoactivas"23.

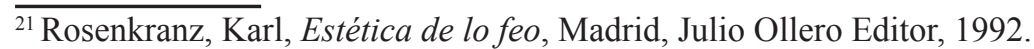

${ }^{22}$ Por mencionar algunos: Jan Fabre, Candida Höfer y Jake y Dinos Chapman.

${ }^{23}$ Panera Cuevas, Francisco, Barrocos y Neobarrocos... op. cit., 2007, p. 52.
} 
La unión entre arte y tecnología que se ha producido en la era post-internet ha conseguido recrear lo máximo posible el misticismo barroco a través de la transformación del espacio. El espacio programado ha sido definido por el historiador y especialista dedicado a los medios de comunicación Norman Klein como un "espacio [que] permite al espectador/usuario entrar y sentirse como si tuviera opciones ilimitadas, incluso cuando la realidad del espacio está diseñada con extrema precisión para un objetivo o «modo de ver» concreto" 24 . De esta forma se describe Internet como una especie de trompe l'oeil; una ilusión a modo de trampantojo.

Algunas de las vídeo-instalaciones de la exposición, como Walking on thin air del colectivo Assume Vivid Astro Focus (2003), buscaban, dentro de lo posible, recrear esta situación de inmersión a través de pintura, vídeo y sonido. En una época en la que la cultura visual ha entrado en una crisis marcada por la sobreinformación y la saturación de imágenes, la vídeo instalación se ha convertido en el nuevo bel composto berniniano. La preocupación ilusionista del Barroco es equiparable a la búsqueda de la inmersión total de las nuevas tecnologías ${ }^{25}$. Hay varias formas de hacer que el espectador se olvide del medio para centrarse en el mensaje a través de la inmersión. Internet se ha convertido en una de las plataformas de desarrollo del Neobarroco.

Lo que tienen en común el arte de los nuevos medios y la escenografía barroca es que ambos pretenden difuminar la barrera entre realidad y ficción en una mezcla entre ilusionismo e intertextualidad ${ }^{26}$. La instalación de Assume Vivid Astro Focus, igual que un trampantojo barroco pintado con cuadratura, se ha convertido en un lugar donde el espacio ficticio transciende el espacio físico a través de la ilusión.

La exposición, como sus obras, desdibujaron las fronteras entre realidad y ficción explotando al máximo la escenografía barroca. El espacio expositivo se convierte en la alegoría del mundo como gran teatro que tanto fascinó a los dramaturgos del siglo XVII. Ni el bel composto de Bernini ni la Gesamtkunstwerk de Wagner son ya relevantes. La obra de arte total es neobarroca.

\section{Subvertir el discurso: capitalismo y colonialismo en Principio Potosí}

Una de las consecuencias principales de la conquista de América fue la creación de un nuevo sistema económico basado en la explotación indígena que permitió que el Imperio español financiara tanto guerras como empresas artísticas. Esto se hizo posible, entre otros,

\footnotetext{
$\overline{{ }^{24} \ldots \text { op. cit., } 2007}$, p. 297.

${ }^{25}$ Ndalianis, Angela, Neo-baroque aesthetics... op. cit., pp. 81-96.

${ }^{26}$ Ibídem, p. 152; Virilio, Paul, "El instante real", en Buci-Glucksmann, Christine, Volumen 2... op. cit., pp. 81-87.
} 
gracias a la riqueza del Cerro Rico de Potosí, "octava maravilla del mundo"27. En España la explotación de América y el florecimiento cultural del Siglo de Oro son dos caras de una misma moneda. Por esta razón, el Museo Reina Sofía decidió realizar una exposición con motivo de la celebración del bicentenario de los procesos de independencia de la mayoría de las antiguas colonias americanas.

La Villa Imperial de Potosí, en la actual Bolivia, fue una de las ciudades más importantes del mundo durante la época de ocupación colonial. Debido a la explotación minera llegó a tener una población superior a la de Londres o París, pero los trabajadores indígenas, controlados por la población criolla, subsistían en condiciones inhumanas que en la exposición se compararon con otros abusos de la Declaración Universal de los Derechos Humanos que se llevan a cabo hoy en día. Los comisarios de Principio Potosí denunciaban el poder que ejercieron los colonizadores sobre los pueblos indígenas. Esta relación de poder se impuso en 1573 en las Ordenanzas del Perú para un buen gobierno promulgadas por el Virrey Francisco de Toledo. En ellas, se restablecía la mita, un sistema de regulación del trabajo que condenaba a los mineros - mitayos - al trabajo forzoso ${ }^{28}$.

Los procesos de explotación minera que trajeron consigo la conquista y colonización de América y el dominio de los medios de producción por parte de los colonizadores podrían determinarse como el inicio de la modernidad. Descubrir territorios más allá de Europa supuso la apertura de nuevas rutas comerciales. El sistema feudal dio paso a la globalización y la instauración de un nuevo modelo económico, el capitalismo. En este contexto, la plata extraída en Potosí fue clave para el mantenimiento de un imperio en decadencia con frecuentes problemas económicos ${ }^{29}$.

Los comisarios de Principio Potosí buscaron la confrontación de obras de artistas contemporáneos con otras producidas durante la presencia española en el Virreinato de Perú. El mensaje que manda la exposición es claro: el mercado global nació como consecuencia del colonialismo. En esta línea, en uno de los ensayos del catálogo de la exposición Fátima Olivárez introduce brevemente un concepto en el que merece la pena profundizar. Al hablar de las distintas representaciones del apóstol Santiago, Olivárez introduce la versión de "Santiago como empresario moderno" ${ }^{30}$.

La importancia de esto reside, primero, en que Santiago era el patrón de Potosí y, segundo, en que el apóstol constituye uno de los mitos fundamentales en la construcción de la identidad de la monarquía hispánica. Santiago fue una de las figuras clave en la evangelización de América.

\footnotetext{
${ }^{27}$ Cita de fray Diego de Ocaña en Álvarez, Arturo (ed.), Un viaje fascinante por la América Hispana del Siglo XVI, Madrid, Studium, 1969, p. 185.

${ }^{28}$ Choque Canqui, Roberto, "La Mit'a”, en Creischer, Alice et al., Principio Potosí: ¿cómo podemos cantar el canto del Señor en tierra ajena?, catálogo de la exposición (Madrid, Museo Reina Sofía, del 12 de mayo al 6 de septiembre de 2010), Madrid, Museo Reina Sofía, 2010, pp. 233-234.

${ }^{29}$ Ver: Lopezosa Aparicio, Concepción (coord.), El oro y la plata de las Indias en la época de los Austrias, Madrid, Fundación ICO, 1999.

${ }^{30}$ Creischer, Alice et al., Principio Potosí... op. cit., p. 34.
} 
La archiconocida historia de la aparición de Santiago — santo militar por excelencia - en la batalla de Clavijo se adaptó durante la conquista de Cuzco a las necesidades de los españoles. Santiago "Matamoros" pasó a convertirse en Santiago "Mataindios", pero lo más interesante es que los incas identificaron la figura del apóstol con la de su dios del trueno, Illapa ${ }^{31}$. Este sincretismo, manifestado en pintura colonial desde aproximadamente finales del siglo XVI, fue el resultado del cruce entre el cristianismo europeo y lo que quedaba de la cultura prehispánica.

La figura del santo acusa la relación entre arte, religión y economía que los comisarios revelan en el propio subtítulo de la exposición — “¿cómo podemos cantar el canto del Señor en tierra ajena?" - tomado de uno de los salmos del Antiguo Testamento. Santiago es, además, uno de los nexos de unión entre España y Potosí. No solo por ser el santo patrón de los dos sitios, sino por configurarse como mito fundacional en ambos lugares. El milagro legitimador que se usa para intimidar a los indios es el mismo tipo de propaganda que se empleaba en España para justificar el poder de la monarquía y la supremacía del catolicismo. La iconografía de Santiago se adaptó siguiendo las necesidades de la corona, ya fuera a "Matamoros", "Mataindios" o, como describe Olivárez, a "empresario moderno".

Durante la Edad Moderna, la imagen de Santiago se puso al servicio del poder para representar los intereses de la Corona y la Iglesia al otro lado del Atlántico. Actualmente, la bandera y el eslogan son el nuevo caballo blanco. La instrumentalización ideológica del arte fue uno de los temas clave en las exposiciones contemporáneas que, como Principio Potosí o El d_efecto barroco, ahondaban en la vertiente colonial del Barroco histórico. El papel propagandístico de la cultura hizo posible la colonización del imaginario americano.

Es más, la sincretización del apóstol Santiago con dioses locales y otras advocaciones cristianas hizo posible el mito de América como tabula rasa que los españoles tuvieron la oportunidad de rellenar a su gusto, idea que expone por primera vez Pedro Mártir de Anglería (humanista italiano al servicio de los Reyes Católicos) en sus Décadas del Nuevo Mundo publicadas entre 1494 y $1525^{32}$. Edmundo O'Gorman da un paso más e indica que América no se descubrió, sino que es una invención europea ${ }^{33}$. Tanto el mito de la tabula rasa como el de la invención de América responden a la "arrogancia inconsciente" del europeo, que radica en creer que todo lo que se escapa a su control y le resulta desconocido no existe hasta que no tiene consciencia de ello ${ }^{34}$. Lo desconocido - y por tanto inexistente- se convierte, por necesidad, en nuevo.

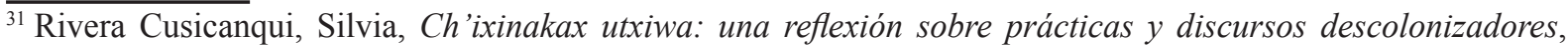
Buenos Aires, Tinta Limón, 2010, p. 30; Mújica Pinilla, Ramón, La imagen transgredida. Ensayos de iconografía peruana y sus políticas de representación simbólica, Lima, Fondo Editorial del Congreso del Perú, 2016, pp. 6085.

${ }^{32}$ Gruzinski, Serge, La guerra de las imágenes. De Cristóbal Colón a Blade Runner (1492-2019), México D. F., Fondo de Cultura Económica, 1994, p. 40.

${ }_{33}$ O’Gorman, Edmundo, La invención de América. La universalización de la cultura occidental, México, Universidad Nacional de México, 1958.

${ }^{34}$ Mignolo, Walter, The idea of ... op. cit., p. 264.
} 
Este tipo de afirmaciones explican las estrategias utilizadas para justificar los procesos de aculturación que pusieron en marcha los españoles tras la conquista. Como consecuencia, la circulación de imágenes fue clave para hacer efectiva la colonización y evangelización de América. No obstante, sin los creadores indígenas hubiera sido imposible la integración de las formas de arte híbridas en el imaginario popular ${ }^{35}$. La estructura divisoria de centro/periferia que durante tanto tiempo se ha utilizado para definir las manifestaciones artísticas americanas hechas en la Edad Moderna es insuficiente para representar el contexto americano. El Barroco que se produce en América es una amalgama de influencias europeas (española, italiana, francesa y holandesa, sobre todo) unido a una tradición local preexistente y que no desapareció del todo tras la conquista. Principio Potosí pretendía evitar la fetichización del Otro americano y la idea de arte colonial como "arte de segunda" no comparando la pintura colonial andina con pintura europea de la misma época. De hecho, la exposición El Tornaviaje, programada para noviembre de 2020, será la primera en combatir desde el Museo del Prado este tipo de afirmaciones y recuperar el arte colonial como parte esencial del arte hispánico.

Principio Potosí se produjo en un contexto muy distinto a Arte en Iberoamérica. La muestra fue comisariada por Creischer, Hinderer y Siekmann. Hasta el año 2009, la socióloga y activista Silvia Rivera Cusicanqui también formó parte del equipo curatorial. Esta fue una de las primeras exposiciones dedicadas a activar políticas decoloniales dentro del museo, renegando del discurso hegemónico de la Historia del Arte en favor de las Historias del Arte que subvierten el eje norte-sur para poner en valor prácticas político-artísticas latinoamericanas. La idea era repensar América Latina desde la institución museística articulando el debate en torno a los temas tratados en la exposición: la acumulación originaria, la globalización, la exclusión social y la precariedad laboral.

Sin embargo, Principio Potosí se ha definido como un proyecto fallido ${ }^{36}$. Para empezar, la exposición buscaba problematizar la relación entre España y las colonias, pero solo eran latinoamericanos nueve de los treinta colectivos y artistas contemporáneos que participaron ${ }^{37}$, eliminando la posibilidad de ejercer la capacidad enunciatoria que demanda Spivak para subvertir el discurso hegemónico ${ }^{38}$. Si bien es cierto que en la exposición participaron artistas y colectivos pertenecientes a minorías no europeas más allá de Latinoamérica, el grueso de los artistas contemporáneos era de origen europeo, muchos de ellos alemanes, como los propios comisarios.

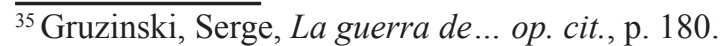

${ }^{36}$ De Diego, Estrella, "Principio Henri Rousseau", en El País, 28 de agosto de 2010. «https://elpais.com/ diario/2010/08/28/babelia/1282954356 850215.html» [Consultado el 2 de abril de 2019].

${ }^{37}$ Creischer, Alice et al., Principio Potosí... op. cit., pp. 297-299.

${ }^{38}$ Spivak, Gayatri C., "Can the subaltern speak?", en Nelson, Cary y Larry Grossbe (eds.), Marxism and the interpretation of culture, Londres, Macmillan Education, 1988, pp. 271-313. https://doi.org/10.1007/978-1-34919059-1_20
} 
Pero sin duda el aspecto más criticado fue el montaje "esquizoide" de la exposición 39 . Principio Potosí se concibió como una cámara de maravillas leibniziana ${ }^{40}$. La Monadología del filósofo Gottfried Leibniz — que será la base de El pliegue de Deleuze, fundamental para entender el análisis de los fenómenos culturales que abarca el Neobarroco- establece que todo está interconectado a partir de mónadas. Las mónadas, en este caso, eran los objetos de la exposición que se juntaban para formar una yuxtaposición de discursos. En el montaje, esta idea se tradujo en un sistema de barras a modo de andamios del que colgaban las obras, dejando vacíos los muros perimetrales de la sala (fig. 2). La exposición contaba, además, con dos plataformas a las que el espectador podía subir, sillas de árbitro y una escalera ${ }^{41}$.

Figura 2: Vista de la exposición Principio Potosí: ¿cómo podemos cantar el canto del Señor en tierra ajena?

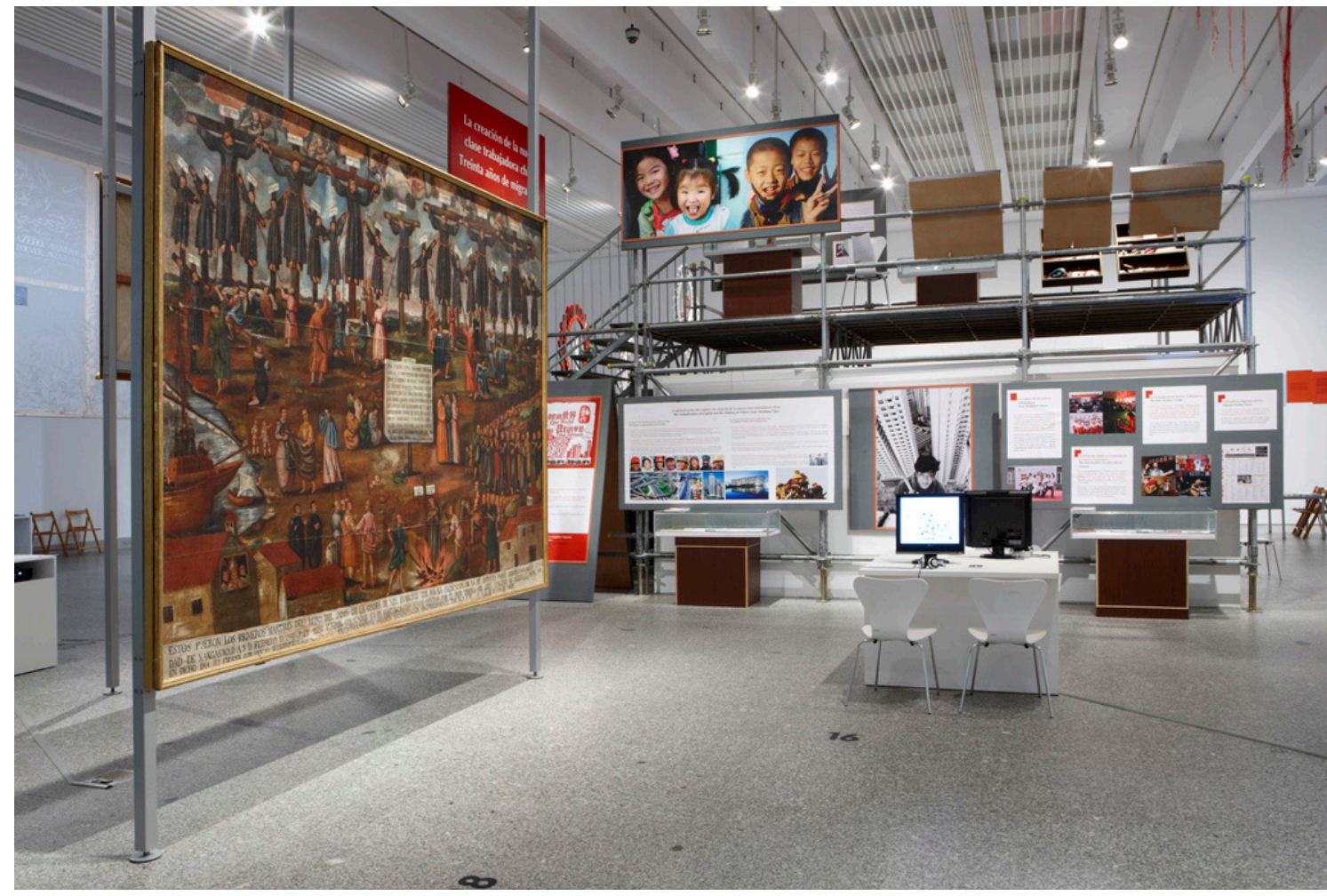

Fuente: Museo Nacional Centro de Arte Reina Sofía.

Incluso el catálogo es un caos de ensayos y entrevistas fragmentadas que continúan en otras partes del libro. Como se puede ver en la elaboración del índice, la lectura se interrumpe continuamente y de forma deliberada. Tanto el catálogo como la pequeña guía explicativa que guiaba al visitante reivindicaban el policentrismo ${ }^{42}$ y se dividían en cuatro recorridos temáticos,

\footnotetext{
${ }^{39}$ Batalla, Juan, "Ezquizoide. Vejámenes, desalineación e histeria crítica. Post-it city + Principio Potosí", en Sauna. Revista de arte, 1 (2014). «http://www.revistasauna.com.ar/01_01/05.html» [Consultado el 14 de mayo de 2019]. ${ }^{40}$ Creischer, Alice et al., Principio Potosí... op. cit., p. 4.

${ }^{41}$ Godoy Vega, Francisco, La exposición como recolonización. Exposiciones de arte latinoamericano en el estado español (1989-2010), Badajoz, Fundación academia europea e iberoamericana de Yuste, 2018, p. 394.

${ }^{42}$ Calabrese, Omar, La era Neobarroca... op. cit., pp. 62-63.
} 
haciendo de Principio Potosí un palimpsesto: "Existe una acumulación originaria que solo se llama as'́; "existen los derechos humanos para tener derechos sobre los humanos”; “cómo podemos cantar el canto del Señor en tierra ajena?" y "mundo al revés". Principio Potosí fue una exposición confusa y así lo refleja la crítica ${ }^{43}$. No había cartelas, el espectador debía orientarse únicamente con ayuda de la guía, por lo que uno de los aspectos más criticados fue la direccionalidad impuesta de la exposición.

El problema radicó en que todas estas estrategias discursivas — más o menos acertadasbuscaban subvertir el discurso colonial, pero la exposición perpetuaba una visión única de la verdad, convirtiéndose así en una exposición fallida en el contexto del bicentenario ${ }^{44}$. Un contexto, además, al que no se alude para nada ya que la exposición no incide en el proceso independentista del siglo XIX, sino que se centra en el periodo colonial de los siglos XVII y XVIII. No obstante, como indica Francisco Godoy, “el montaje también se presentó a modo de réplica de la pintura barroca, donde presentación y ocultamiento impiden la existencia de una única narrativa o linealidad espacial, al menos en términos de formalización de la exposición"45.

La superposición de los recorridos, la confusión que generaba y la concepción liebniziana de la exposición son, precisamente, lo que la convierte en un dispositivo barroco. Fue una exposición sobrecargada, construida pliegue sobre pliegue, siguiendo las premisas básicas del Neobarroco y la filosofía del mundo al revés con la idea de revertir la historiografía colonial ${ }^{46}$. El Barroco de Principio Potosí no solo está presente en la pintura colonial andina que se exhibía y que ayudaba a articular el discurso curatorial, sino que también forma parte del propio display de la muestra.

\section{Políticas culturales en Eld_efecto barroco: Barroco, hispanidad, Latinoamérica}

Jorge Luis Marzo y Tere Badia fueron los comisarios El d_efecto barroco. Políticas de la imagen hispana, que se pudo visitar entre el 9 de noviembre de 2010 y el 27 de febrero de 2011 en el CCCB antes de que itinerara a Quito, Ecuador. Los comisarios apostaron por una exposición documental (fig. 3). El proyecto buscaba criticar el concepto de hispanidad que el Estado español promueve en las Cumbres Iberoamericanas y ejercer una mirada crítica sobre las políticas culturales españolas en Latinoamérica, especialmente cuando se cumplía el bicentenario de las independencias de algunas de las antiguas colonias americanas.

\footnotetext{
${ }^{43}$ Jiménez, José, "Potosíes", en ABC Cultural, 5 de mayo de 2010. «http://hemeroteca.abc.es/nav/Navigate.exe/ hemeroteca/madrid/cultural/2010/06/05/030.html» [Consultado el 2 de abril de 2019].

${ }^{44}$ Godoy Vega, Francisco, La exposición... op. cit., p. 414.

${ }^{45}$ Ibídem, p. 394.

${ }^{46}$ Rivera Cusicanqui, Silvia, Sociología de la imagen: miradas ch 'ixi desde la historia andina, Buenos Aires, Tinta Limón, 2015, pp. 243-249.
} 
Figura 3: Sala de exposición de El d_efecto barroco. Políticas de la imagen hispana.

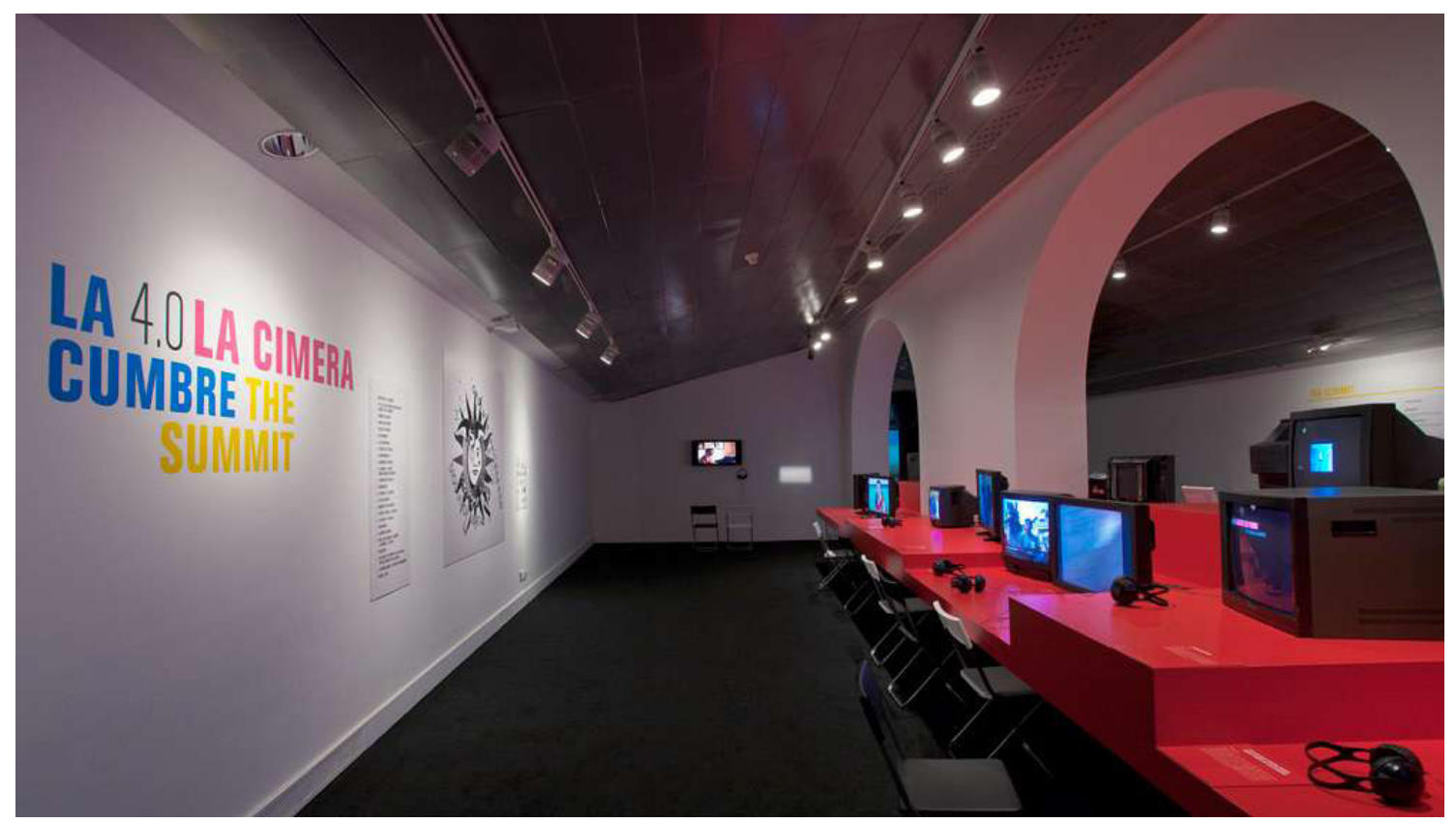

Fuente: CCCB.

La muestra fue la culminación de seis años de investigación en España, México, Chile y Perú. El videoarte y arte de nuevos medios fueron los elegidos para elaborar un discurso expositivo. Con el fin último de mostrar "los mecanismos que han hecho posible la creación de un imaginario oficial de lo hispano" ${ }^{47}$, El d_efecto barroco, igual que Principio Potosí, ahondaba en la idea del arte como medio propagandístico, pero esta vez asociado al concepto de hispanidad. Debemos hacer notar que el concepto de hispanidad - término que, parafraseando a Jorge Luis Marzo, lo dice todo sin decir nada — ${ }^{48}$ que manejan los comisarios surge en el periodo de conquista, unido al mestizaje y la evangelización de los colonizados. Como se indica en el catálogo, "hablar de lo hispano significa hablar de los indios" ${ }^{49}$. Tal y como se entiende el término en Eld_efecto barroco, la hispanidad es un constructo del siglo XIX que nace unido a la concepción del Barroco.

La hispanidad, por tanto, no es un concepto ajeno a España, pero tampoco podemos hablar de hispanidad como algo intrínsecamente español. De hecho, con motivo de la exposición el politólogo Francisco Carballo comentaba que, tras la entrada de España en la Unión Europea, "toca ir a América a ver la verdadera hispanidad" ${ }^{50}$. Por esta razón la exposición no trataba el

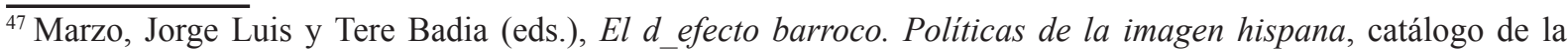
exposición (Barcelona, Centre de Cultura Contemporània, del 9 de noviembre de 2010 al 27 de febrero de 2011), Barcelona, Centre de Cultura Contemporània, 2010, p. 62.

${ }^{48}$ Marzo, Jorge Luis, La memoria administrada ... op. cit., p. 13.

${ }^{49}$ Marzo, Jorge Luis y Tere Badia, El d_efecto barroco... op. cit., p. 78.

${ }^{50}$ Marzo, Jorge Luis, La memoria administrada ... op. cit., p. 356.
} 
Barroco como un estilo artístico suscrito a los siglos XVII y XVIII, sino como el momento de gestación de algunas políticas culturales que todavía están vigentes en el presente.

Para ello, se puso especial interés en el "mito del arte barroco", que en el catálogo de la exposición se describe como: "pieza articular de la hispanidad, uno de los mitos culturales mejor trabados y más resistentes, que en cierto modo forma parte de los sobreentendidos colectivos, y que se ha incorporado incluso a los rituales políticos" ${ }^{51}$. La exposición veía en el Barroco una herramienta política empleada por primera vez en la Edad Moderna pero que se ha mantenido vigente hasta nuestros días.

Para desmantelar el mito barroco Marzo y Badia buscaron obras que manifestaran su inestabilidad. Sin embargo, existe una razón por la que el mito barroco sigue vigente y es que, en España, el Barroco ha tenido un papel importante como propaganda para la construcción de la identidad nacional.

Uno de los motivos por los que el Barroco no ha pasado de moda es su asociación con un periodo de esplendor cultural. Así, uno de los acontecimientos históricos en los que hace hincapié Eld_efecto barroco es en el uso de reproducciones del Museo del Prado en las Misiones Pedagógicas de la Segunda República. En la exposición se podían ver copias de algunos de los cuadros de este Museo del Pueblo, así como fotografías de la época. Esta iniciativa llevada a cabo entre 1931 y 1936 la protagonizaron las obras de los considerados grandes maestros de la pintura española: Velázquez, Goya, El Greco, Murillo, Ribera, Zurbarán... Muchos de ellos representantes del Barroco español ${ }^{52}$.

Precisamente, las obras del Siglo de Oro funcionaban porque el Barroco fue, simultáneamente, un arte popular y burgués, de colonizadores y colonizados ${ }^{53}$. Recientemente, justo en los años precedentes a la exposición, el Barroco volvió a conquistar el imaginario colectivo. Una de las últimas salas de la exposición contaba con un collage de imágenes de prensa de cuando la Selección Española de Fútbol ganó la Eurocopa en 2008. Como la imagen de Santiago "Mataindios", las conquistas de la Selección se constituyeron como mitos perpetuadores de la hispanidad y la historia triunfal de nuestro país. La victoria en época de crisis es una contradicción plenamente barroca, aunque luego precisamente fuera la actitud barroca lo que criticara la prensa deportiva ${ }^{54}$.

Para rematar esta sección dedicada - aunque no sin cierta ironía - al fútbol, se encontraba una reproducción prácticamente a escala del cuadro La rendición de Breda de Velázquez, popularmente conocido como Las lanzas. Pero no era una copia exacta del cuadro original. La imagen que se expuso en El d_efecto barroco formaba parte de la campaña publicitaria

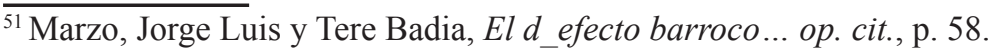

${ }^{52}$ Dennis, Nigel, "Ramón Gaya y el Museo del Pueblo de las Misiones Pedagógicas", en Escritura e imagen, 7 (2011), pp. 15-26. https://doi.org/10.5209/rev ESIM.2011.v7.37771

${ }^{53}$ Gruzinski, Serge, La guerra de ... op . cit., p. 159.

${ }^{54}$ Besa i Camprubí, Ramón, "Demasiado barrocos", en El País, 17 de junio de 2010. «https://elpais.com/ diario/2010/06/17/deportes/1276725602_850215.html» [Consultado el 10 de abril de 2019].
} 
que lanzó CEPSA para patrocinar a España en el Mundial de Fútbol de 2010 bajo el lema "El mundo vuelve a ser nuestro". En ella, los soldados españoles que aparecen en el cuadro vestían camisetas y bufandas de la Selección y ondeaban una gran bandera de España. Esta imagen se ha llegado a calificar como "profética" ya que, aunque la campaña publicitaria se lanzó antes de que se conocieran qué equipos se iban a disputar la final, vaticinó el encuentro entre España y Holanda ${ }^{55}$. La imagen siempre se ha usado como un sistema de control e instrumento ideológico. En la Edad Moderna, la imagen tenía valor testimonial y servía como documento legitimador de políticas e historias, como se pretendía hacer entender en la exposición. Ni la obra de Velázquez ni la reinterpretación de CEPSA son imágenes apolíticas.

Las obras audiovisuales, las entrevistas dirigidas por los comisarios a artistas, intelectuales y políticos, las imágenes de la Selección y el Museo del Pueblo compartían el espacio expositivo para elaborar un discurso crítico sobre la apropiación política de la cultura. Esto se refleja tanto en las obras escogidas que hemos mencionado como en el propio display de la exposición. Eld_ efecto barroco critica que España se haya vendido al turismo y se haya convertido en una marca, hasta el punto de convertir la cultura en un producto de consumo subordinado a la maquinaria política. A este capitalismo cultural — término que se ha puesto recientemente de moda para hablar de la mercantilización de la cultura $-{ }^{56}$ se ha llegado a través del Barroco, que se vende como los ideales de la hispanidad. Así, estudiando de forma crítica el papel de la monarquía, la brecha entre lo popular y lo moderno y los mitos fundacionales de nuestro país a través de la relación con América Latina, se llega a la conclusión de que el arte — principalmente el producido en el Siglo de Oro - se ha convertido en una herramienta legitimadora de la política nacional.

Desde finales de los años setenta se ha producido un proceso "barroquizador" en toda Latinoamérica impulsado, sobre todo, por instituciones privadas, pero también por las dictaduras militares de Chile, Perú y Bolivia. El Barroco colonial se recuperó como símbolo de estatus cultural y como reclamo turístico ${ }^{57}$. Olvidado queda el siglo XIX cuando se quemaban iglesias y demás edificios barrocos en México en señal de protesta contra el régimen colonial. A partir de los sesenta, "el Barroco [en América Latina] ya no es un lastre farragoso, es simplemente un negocio" $" 58$.

Además, con el surgimiento de los estudios poscoloniales y el renovado interés por el Barroco y su relación con la modernidad, surgió también una línea de investigadores que afirmaban que América ya era Barroca antes incluso de que llegaran los españoles. El escritor cubano Alejo Carpentier dictaminó en 1979: "nuestro arte siempre fue barroco: desde la

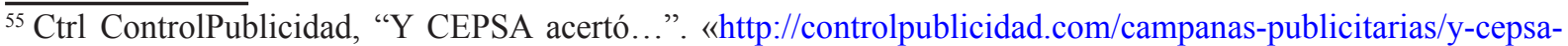
acerto/» [Consultado el 5 de junio de 2019].

${ }^{56}$ Llopis Goig, Ramón, "La cultura en la época del capitalismo cultural. Tendencias y controversias", en Culturas. Revista de gestión cultural, 1 (2014), pp. 46-60. https://doi.org/10.4995/cs.2014.3180

${ }^{57}$ Marzo, Jorge Luis, "Neo, post, ultra, pre, para, contra, anti. Modernidad, Barroco y capitalismo en el arte contemporáneo mexicano", en Estudios culturales, 1 (2012), pp. 81-94.

${ }^{58}$ Marzo, Jorge Luis, La memoria administrada... op. cit., pp. 179-197.
} 
espléndida escultura precolombina y el de los códices, hasta la mejor novelística actual de América" 59 . Lo mismo afirmaba otro literato argentino, Alfredo Roggiano, cuando dijo que "América es barroca antes del barroquismo europeo y por mucho tiempo después: lo es y lo seguirá siendo" 60 .

Si durante la Edad Moderna las imágenes barrocas habían servido como medio propagandístico, ahora es el propio discurso el que se usa con fines identitarios. Hasta el momento hemos visto dos tipos de estrategia a la hora de usar el relato barroco como instrumento ideológico y de propaganda. La primera, llevada a cabo por la historiografía española hasta prácticamente nuestros días, pasa por ignorar por completo la relación entre el Barroco español y la expansión colonial. La segunda, la de los intelectuales latinoamericanos de apropiarse del discurso del colonizador y hacerlo suyo para subvertir las relaciones de poder tras el auge de los estudios poscoloniales.

Este cambio de mentalidad puede haber estado influenciado por los estudios sobre lo neobarroco que, como hemos visto, surge a finales de los años setenta, a la par que la apropiación nacional del Barroco por parte de los teóricos latinoamericanos con el objetivo de identificar América Latina con la posmodernidad ${ }^{61}$. El Neobarroco de Sarduy se ha leído en clave revolucionaria y para algunos autores surge en el contexto del boom latinoamericano y la Transición española como una apropiación crítica de la historia para reescribir los códigos impuestos por los colonizadores ${ }^{62}$. Pero sobre todo, en la exposición se recalca el sentido de arte en periodo de transición.

Si la hispanidad es una característica intrínseca del Barroco y Latinoamérica es barroca, cabe preguntarse qué significa ser hispano, si es que sigue significando algo. Este es el trasfondo de Eld_efecto barroco, que todavía hoy sigue planteándonos interrogantes sobre la prevalencia de la hispanidad, el uso político del arte y la efectividad del Barroco como instrumento político y de propaganda. Es más, el mejor resumen de las políticas culturales de nuestro país en los últimos años es el trabalenguas que plantearon los comisarios de la exposición en la portada del catálogo: "Lo hispano está embarrocado, / ¿quién lo desembarrocará? / El desembarrocador que lo desembarroque / buen desembarrocador será".

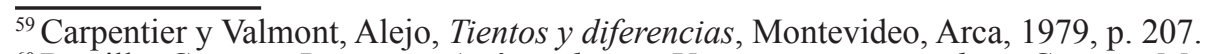

${ }^{60}$ Bustillo, Carmen, Barroco y América latina. Un itinerario inconcluso, Caracas, Monte Ávila Editores, 1988, p. 22.

${ }^{61}$ Marzo, Jorge Luis, "Neo, post, ultra... op. cit., p. 82.

${ }^{62}$ Ndalianis, Angela, Neo-baroque aesthetics... op. cit., pp. 12-14.
} 
4. El vigesimotercer momento barroco

Desde finales del siglo xx se advierte un fuerte interés por la recuperación del Barroco histórico que ha llevado a su resignificación. La recuperación y resignificación del Barroco que se ha producido en el siglo Xxi se ha trasladado a los discursos expositivos de galerías y museos contemporáneos, lo que demuestra el interés del mundo curatorial por revisar el seicento español. Barrocos y Neobarrocos. El infierno de lo bello, Principio Potosí: ¿cómo podemos cantar el canto del Señor en tierra ajena? y El d_efecto barroco. Políticas de la imagen hispana son tres ejemplos de ello. El análisis de estas exposiciones (celebradas todas en instituciones públicas y cercanas en el tiempo) ha aportado más información sobre preocupaciones contemporáneas que sobre el Barroco histórico. Las muestras tratan la relación entre España y Latinoamérica cuando se cumplían doscientos años de la independencia de las colonias, el rechazo a la posmodernidad en un momento de declive y los momentos de transición y crisis en la era de la sobreinformación y la saturación de imágenes.

Estas exposiciones han aportado tres maneras distintas de incorporar el imaginario barroco en muestras de arte contemporáneo, pero todas las muestras coinciden en que el Barroco ha trascendido la etiqueta de categoría estilística y se ha convertido en una corriente transhistórica. Las muestras, además, presentan el Barroco, a través del Neobarroco, como el epítome de la posmodernidad en nuestro país.

El Neobarroco que hemos visto en estas exposiciones es, ante todo, una forma de repensar nuestra relación con el pasado a través de tropos que se usan para construir narraciones sobre el presente. Una de las características que Calabrese identifica como propias del movimiento Neobarroco y que podemos observar en las tres muestras es el policentrismo. Esta cualidad está presente en el marco teórico de Barrocos y Neobarrocos, en el montaje en forma de palimpsesto de Principio Potosí y en el rechazo al modelo de centro/periferia de los academicistas latinoamericanos. Como resultado, la barroquización de la imagen contemporánea surge a partir de la recuperación de conceptos barrocos (o conceptualmente barrocos) como el trampantojo, la belleza de lo imperfecto, la transmutación del cuerpo y, sobre todo, la puesta en escena que ha hecho posible la concepción del mundo como un gran teatro.

Además, esta resignificación del Barroco histórico también pasa por la inclusión de América Latina en la historiografía, algo que hasta el momento se había excluido del discurso oficial. Este es uno de los aspectos más novedosos de las muestras, ya que el interés por el Barroco latinoamericano se ha manifestado principalmente en proyectos curatoriales contemporáneos, exceptuando la labor de difusión del Museo de América en Madrid. El Neobarroco se ha constituido como un nuevo medio de construcción de políticas identitarias, igual que lo fue el Barroco histórico en su momento y no se presenta como una corriente aislada, sino que 
está estrechamente relacionado con la resignificación del Barroco como algo propiamente americano.

El relato barroco se ha convertido en una herramienta política de doble filo. La recuperación barroca en la que se basaban estos proyectos expositivos se centraba en el bicentenario de las declaraciones de independencia de las antiguas colonias americanas. No obstante, ninguna de las exposiciones aquí tratadas celebradas en este contexto hizo alusión a los procesos revolucionarios del siglo xIx. El caso americano en Prinicpio Potosí y El d_efecto barroco (y, en menor medida, también en Barrocos y Neobarrocos) se ajustaba a un periodo concreto: la colonización en los siglos XVII y XVIII.

El Barroco se presenta pues, como una política cultural. Desde la Edad Moderna la imagen barroca se ha convertido en uno de los mecanismos de propaganda al servicio del poder. El Barroco se ha asociado con el mito de la hispanidad en repetidas ocasiones a lo largo de la historia, un tema en el que ahondan las exposiciones analizadas en el presente trabajo. Pero, como se explicita en estas exposiciones, numerosos teóricos e historiadores latinoamericanos han defendido la identidad barroca del continente americano, cualidad que dicen estaba presente en América antes incluso de la conquista y colonización.

La apropiación del Barroco en Latinoamérica ha supuesto la deconstrucción del relato oficial y ha ayudado a subvertir el modelo centro/periferia que ha dominado la historiografía hasta finales del siglo xx y que presentaba el arte producido en América durante el periodo colonial como un "arte de segunda" incapaz de compararse al arte producido en Europa en la misma época. El mito de la hispanidad, hasta ahora síntoma del Barroco, se ha subvertido para convertirse en algo intrínsicamente latinoamericano, lo que plantea serias reflexiones sobre la vigencia del término "hispanidad", la prevalencia del Barroco como instrumento político y de propaganda y el uso político del arte. De esta forma, estas exposiciones celebraron el proceso de independencia problematizando el periodo colonial, algo que hasta el momento solo se ha hecho en instituciones de arte contemporáneo.

Barrocos y Neobarrocos, Principio Potosí y El d_efecto barroco fueron exposiciones críticas con la doble vertiente del Barroco, que por un lado marca el Siglo de Oro de la cultura española y, por otro, un periodo de explotación colonial. La apropiación neobarroca del discurso colonizador fue clave en la elaboración de estos proyectos, que incorporaron el mito barroco como mediador en la relación entre España y América Latina y como medio para la administración de la memoria. Pero, sobre todo, estas exposiciones plantean el Barroco como algo más que una etiqueta estilística. El Barroco como se plantea síntoma y diagnóstico de nuestra sociedad, como ejemplo y como excusa. La etiqueta de "barroco" es independiente de la fecha de producción de una obra pues, aunque estas exposiciones presentaban obras realizadas antes, durante y después del siglo XVII, todo se enmarca en la categoría de (neo)barroco. 
Estableciendo paralelismos con la sociedad, política y cultura de la España del Siglo de Oro, Barrocos y Neobarrocos, Principio Potosí y El d_efecto barroco activaron el debate sobre lo que significa ser barroco en el siglo XxI, ya fuera de manera conceptual, confrontando obras coloniales con otras de factura moderna, o de forma documental. Las exposiciones aquí tratadas se han convertido en espacios para la reflexión en torno a la relación entre el Barroco histórico y el arte contemporáneo a través de dos estrategias discursivas: la subversión del mito de la hispanidad y el Neobarroco. Así, la persistencia del Barroco histórico solo se entiende al hablar del Barroco en términos de adicción, como si fuera una droga de la que no podemos prescindir ${ }^{63}$. Eso explicaría la persistencia de los momentos barrocos de Eugenio d'Ors y la retombée de Severo Sarduy. En esta línea, se podría argumentar incluso que estamos viviendo el vigesimotercer momento barroco de la historia, pues estas exposiciones son la prueba de que hemos vuelto a recaer en el Barroco.

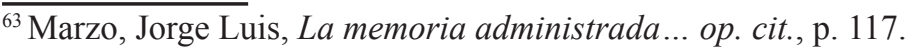

